\title{
Exopolysaccharide Production by Pseudomonas NCIB11264 Grown in Batch Culture
}

\author{
By A. G. WILLIAMS* AND J. W. T. WIMPENNY \\ Department of Microbiology, University College, Cardiff CF2 ITA
}

(Received I8 March 1977)

\begin{abstract}
Fermentation studies using batch culture indicated that exopolysaccharide production by Pseudomonas NCIBI 264 in a chemically defined medium increased under conditions of nitrogen limitation and excess carbon substrate at $\mathrm{pH}$ values above 6 . The polysaccharide was formed from a variety of carbon substrates and its composition was not affected by the nature of the carbohydrate source. Polysaccharide formation did not increase in media containing small amounts of phosphate, and, as in secondary metabolite production, it started late in the exponential growth phase continuing maximally after growth had ceased. The efficiency of glucose conversion into exopolysaccharide was low.

Colorimetric, viscometric, and total carbon estimation techniques are described for determining exopolysaccharide levels in cell-free culture supernatants.
\end{abstract}

\section{INTRODUCTION}

The effect of environmental conditions on the production of extracellular polysaccharide by a number of microbial species has been studied both with growing cultures and with washed cell suspensions. Strains differ in their responses to the effects of changes in environment. Limitation of the nitrogen, phosphorus or sulphur source in the presence of excess carbohydrate may lead to increased synthesis of polysaccharide, although the amount is also affected by the oxygen and $\mathrm{pH}$ requirements of the individual strain. Strains also differ in carbon source utilization, mineral requirements and temperature optima for exopolysaccharide synthesis (Sutherland, 1972).

Extracellular slime is a characteristic of certain Pseudomonas strains and the formation of a complex exocellular slime has been reported in strains of $P$. aeruginosa under various cultural conditions (Brown, Scott-Foster \& Clamp, 1969; Goto et al., I97I, 1973). The influence of iron and sulphite on growth and formation of slime and pigment by certain $P$. aeruginosa strains has been determined (Palumbo, 1972, I973), as has the range of carbohydrate sources which support exopolymer formation by Zoogloea ramigera (Parsons \& Dugan, 197I).

Pseudomonas PBI, isolated from a carbohydrate-rich effluent, synthesized large quantities of an extracellular polysaccharide slime when grown in both complex and chemically defined media with either glucose or sucrose as carbon source. Some of the chemical and physical characteristics of the polymer have been determined (Williams, Wimpenny \& Lawson, 1973; Williams, 1974). The work reported here is part of an investigation undertaken to assess the effects of medium composition and environmental factors on the formation of exopolysaccharide by Pseudomonas PBI when grown in batch culture.

* Present address: Department of Biochemistry, Hannah Research Institute, Ayr, Scotland KA6 5 HL. 


\section{METHODS}

Growth and maintenance of culture. Pseudomonas PBI (Williams \& Wimpenny, 1976) has been deposited in recognized culture collections as NCIBI 1264 and ATCC31260. It is an aerobic, nutritionally non-demanding,


$\mathrm{KH}_{2} \mathrm{PO}_{4}\left(5.44 \mathrm{~g} \mathrm{l}^{-1}\right)$ and a mineral salts solution $\left(6 \mathrm{ml} \mathrm{l}^{-1}\right)$ containing $\left(\mathrm{g} \mathrm{l}^{-1}\right): \mathrm{MgSO}_{4} \cdot 7 \mathrm{H}_{2} \mathrm{O}(\mathrm{IO}), \mathrm{MnCl}_{2}$. ${ }_{4} \mathrm{H}_{2} \mathrm{O}(\mathrm{I} \cdot 0), \mathrm{FeSO}_{4} \cdot 7 \mathrm{H}_{2} \mathrm{O}(0 \cdot 4)$ and $\mathrm{CaCl}_{2} \cdot 2 \mathrm{H}_{2} \mathrm{O}(0 \cdot \mathrm{I})$. The carbon source was glucose $(2 \%, \mathrm{w} / \mathrm{v})$ unless otherwise indicated and the complete medium was buffered to $\mathrm{pH} 7 \cdot 0$ with $\mathrm{I} \mathrm{M}-\mathrm{KOH}$ (Gray et al., 1966). Cultures $(200 \mathrm{ml})$ were grown in $\mathrm{I} 1 \mathrm{baffled}$ Erlenmeyer flasks at $30 \pm \mathrm{I}{ }^{\circ} \mathrm{C}$ with gyratory incubation (I20 rev. $\mathrm{min}^{-1}$ ). A 101 capacity vessel (L. H. Engineering, Stoke Poges, Buckinghamshire) with facilities for the automatic control of temperature, $\mathrm{pH}$, foaming and gas flow rates was used for large-scale batch fermentations.

The organism was maintained at $4{ }^{\circ} \mathrm{C}$ on nutrient agar slopes, supplemented with glucose $(2 \%, \mathrm{w} / \mathrm{v})$.

Analytical methods. The ammonia content of the growth medium and spent fermentation liquor was measured with Nessler's Reagent or as ammonia-nitrogen (Solorzano, 1969). Glucose was estimated using glucose oxidase (Sigma).

Exopolysaccharide samples were recovered from culture supernatants by precipitation with propan-2-ol and dried under reduced pressure at a temperature not exceeding $40^{\circ} \mathrm{C}$. Solutions were desalted by dialysis against distilled water at $4{ }^{\circ} \mathrm{C}$ using dialysis tubing that had been pre-washed with $0 \cdot 0$ I M-EDTA/I \% (w/v) $\mathrm{Na}_{2} \mathrm{CO}_{3}$ solution (Williams, I974). The total hexose content of unhydrolysed polysaccharide was determined colorimetrically by the cysteine-sulphuric acid reaction with a glucose standard (Dische, 1962a). Deoxyhexose was also measured by a cysteine-sulphuric acid reaction (Dische, $1962 b$ ). The acetate content of the unhydrolysed exopolysaccharide material was estimated using the colorimetric procedure of McComb \& McCready ( I957). Pyruvic acid was determined in partial acid hydrolysates of the polymer ( $\mathrm{I} \mathrm{M}-\mathrm{HCl}, 5 \mathrm{~h}$, $100{ }^{\circ} \mathrm{C}$ ) utilizing the pyruvate-specific method of Friedman \& Haugen (I943). The monosaccharide components of the crude polysaccharide preparations were identified in complete acid hydrolysates $(0.5 \mathrm{M}-$ $\left.\mathrm{H}_{2} \mathrm{SO}_{4}, \mathrm{I} 6 \mathrm{~h}, 100^{\circ} \mathrm{C}\right)$ by descending paper chromatography in butan-1-ol/pyridine/water (6:4:3, by vol.). The monosaccharides were detected with $p$-anisidine hydrochloride spray reagent.

Total protein was determined in washed cell suspensions by the method of Lowry et al. (I95I), after cell lysis with an equal volume of $\mathrm{I} \mathrm{M}-\mathrm{NaOH}$ for $5 \mathrm{~min}$ at $100^{\circ} \mathrm{C}$. The standard protein solutions (bovine serum albumin) were treated in an identical manner.

\section{Quantitative estimation of polysaccharide in fermentation liquor}

(i) Gravimetric method. The addition of 3 vols of chilled propan-2-ol, ethan-I-ol or acetone to the cooled cell-free liquor quantitatively precipitated exopolysaccharide from spent fermentation medium previously desalted by dialysis against distilled water for $24 \mathrm{~h}$ at $4{ }^{\circ} \mathrm{C}$. The polysaccharide was recovered by entwining the fibrous mass around a glass rod, by filtration or by centrifugation, and dried for at least $48 \mathrm{~h}$ at $40^{\circ} \mathrm{C}$ under reduced pressure before weighing. This procedure was only reproducible for polysaccharide concentrations above $500 \mu \mathrm{g} \mathrm{ml}^{-1}$. Assays were therefore developed that would accurately and reproducibly detect $10 \mu \mathrm{g}$ differences in the $\mathrm{o}$ to 100 and $\mathrm{o}$ to $250 \mu \mathrm{g} \mathrm{ml}^{-1}$ ranges.

(ii) Colorimetric method. The phenol-sulphuric acid method of Dubois et al. (I956) was applied to I ml of the exopolysaccharide solution containing o to $250 \mu \mathrm{g}$ polysaccharide $\mathrm{ml}^{-1}$ previously dialysed to remove free glucose. All dialysis tubing was pre-treated by repeated washing in a $0.01 \mathrm{M}-\mathrm{EDTA} / \mathrm{I} \%(\mathrm{w} / \mathrm{v}) \mathrm{Na}_{2} \mathrm{CO}_{3}$, followed by washing in distilled water until contaminating carbohydrate material was undetectable. This colorimetric method afforded a quick and reliable assay over the range o to $250 \mu \mathrm{g} \mathrm{ml}^{-1}$. A polysaccharide solution containing $100 \mu \mathrm{g} \mathrm{ml}^{-1}$ gave $E_{490}=0.83$.

(iii) Total carbon analysis. This was measured with a Beckman 915 Total Organic Carbon Analyser. The relationship of total carbon (in p.p.m.) to polysaccharide concentration was linear in the 0 to 100 and $o$ to $500 \mu \mathrm{g}$ polysaccharide $\mathrm{ml}^{-1}$ ranges. The instrument was calibrated for the sensitivity range required using potassium biphthalate $\left(2.125 \mathrm{mg} \mathrm{ml}{ }^{-1}\right)$ as the total organic carbon standard, and a $\mathrm{Na}_{2} \mathrm{CO}_{3} / \mathrm{NaHCO}_{3}$ mixture (4.404 and $3.497 \mathrm{mg} \mathrm{ml}^{-1}$ respectively) as the inorganic standard. Solutions were made up in $\mathrm{CO}_{2}^{-}$ free distilled water. Sample volume (35 to $50 \mu \mathrm{l})$ and instrument sensitivity were adjusted to give maximum peak heights with oven temperatures of $300{ }^{\circ} \mathrm{C}$ (inorganic channel) and $1780{ }^{\circ} \mathrm{C}$ (organic channel), at a $\mathrm{CO}_{2}$-free gas flow rate of $160 \mathrm{ml} \mathrm{min}^{-1}$. From the standard curves the peak height data of unknown samples could be converted directly into total carbon (p.p.m.) and hence polysaccharide concentration $\left(\mu \mathrm{g} \mathrm{ml}^{-1}\right)$. Samples were dialysed as before to remove residual carbon substrate, and all values were corrected for volume changes during dialysis. Total carbon estimates obtained were corrected for inorganic carbon content. The presence of non-dialysable carbonaceous material would contribute to the total carbon data obtained. 


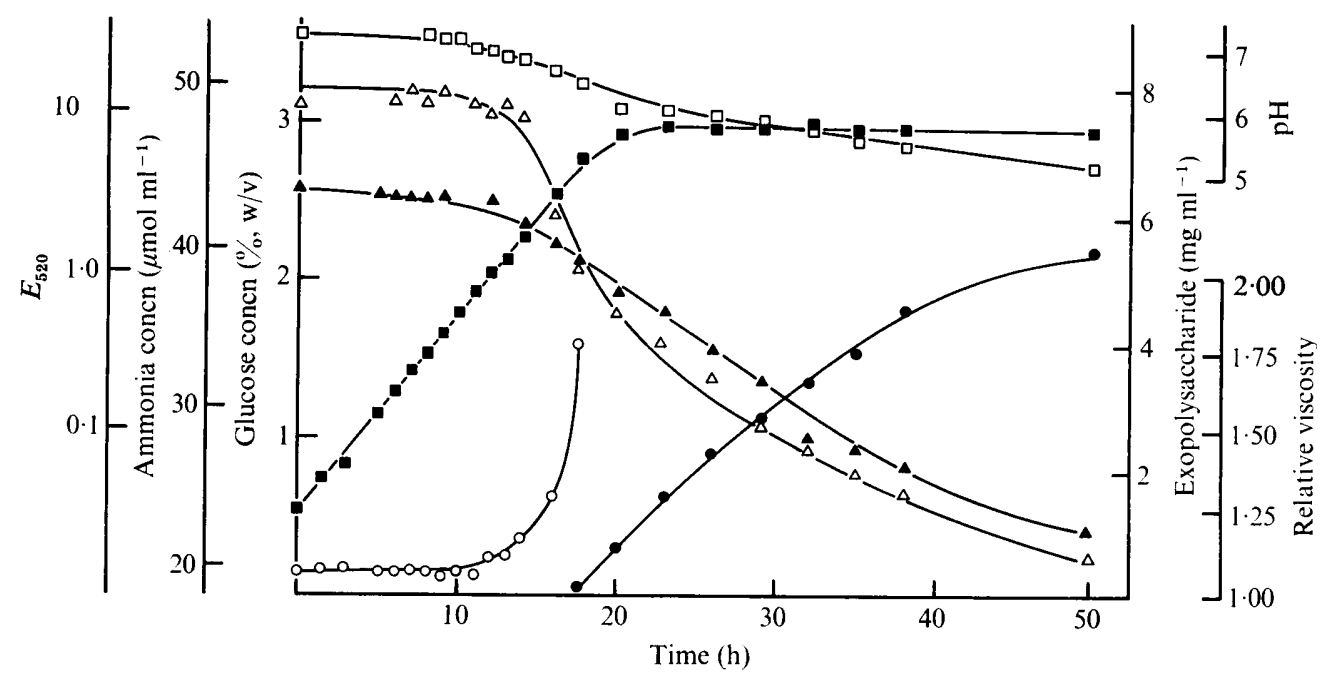

Fig. I. Exopolysaccharide production in a 101 batch fermentation: cell growth, $E_{520}(\square)$, precipitable exopolysaccharide $(\boldsymbol{O})$, concentrations of glucose $(\Delta)$ and ammonia $(\triangle)$ in the fermentation liquor, and culture pH ( $\square$ ). The exopolysaccharide content of the culture supernatant was followed by viscometry during the initial stages of the fermentation $(\bigcirc)$.

(iv) Viscometric method. The relative viscosity was measured using a modified Zimm-Crothers rotating cylinder viscometer with an applied current of $55 \mathrm{~mA}$ at $25 \pm 0.2{ }^{\circ} \mathrm{C}$ (Williams, 1974); there was a linear relationship between polysaccharide concentration and relative viscosity up to $100 \mu \mathrm{g} \mathrm{ml}^{-1}$ (relative viscosity $\equiv \mathbf{I} \cdot 70$ ). This technique was used when polysaccharide could not be precipitated, and had the advantage that dialysis of the samples was unnecessary as the amount of nutrients and salts in the culture supernatant had no measurable effect on the relative viscosities.

\section{RESULTS}

\section{Exopolymer production by Pseudomonas NCIBI 1264 in chemically defined media}

The highest yields of bacteria and polysaccharide were obtained using the medium described for Escherichia coli by Gray et al. (1966) in which the doubling time of the bacterium was I IO to I $20 \mathrm{~min}$. When the $\mathrm{KH}_{2} \mathrm{PO}_{4}$ was replaced by $0.02 \mathrm{M}-\mathrm{KH}_{2} \mathrm{PO}_{4} / \mathrm{O} .02 \mathrm{M}-\mathrm{K}_{2} \mathrm{HPO}_{4}$ buffer ( $\mathrm{pH} 7 \cdot 0)$, the amount of exopolysaccharide fell from 4.9 to $0.14 \mathrm{mg} \mathrm{ml}^{-1}$, the yield of bacteria fell by $55 \%$, and culture $\mathrm{pH}$ after $48 \mathrm{~h}$ growth at $30^{\circ} \mathrm{C}$ changed from 5.5 to $4 . \mathrm{I}$. Poor yields were also obtained in the medium described by Skujins, Potgieter $\&$ Alexander (I965) and although increasing the phosphate content of the medium by using $0.02 \mathrm{M}$ $\mathrm{KH}_{2} \mathrm{PO}_{4} / 0.02 \mathrm{M}-\mathrm{K}_{2} \mathrm{HPO}_{4}$ buffer $(\mathrm{pH} 7 \cdot 0)$ improved the yields of bacteria $\left(E_{520}\right.$ rose from I.0 to $\mathrm{I} \cdot 60$ ) and of polysaccharide (from 0.23 to $0.72 \mathrm{mg} \mathrm{ml}^{-1}$ ) the culture $\mathrm{pH}$ still dropped to $\mathrm{pH} 4$ after $48 \mathrm{~h}$ growth.

\section{Time-course of exopolymer production}

Exopolysaccharide production by Pseudomonas NCIBI I 264 was followed in a 101 batch fermentation, without $\mathrm{pH}$ control, for $50 \mathrm{~h}$ at $30{ }^{\circ} \mathrm{C}$ with volume/volume aeration and an impeller speed of $350 \mathrm{rev}$. $\mathrm{min}^{-1}$. The doubling time of the organism in the defined medium under these conditions was I 40 min. Exponential growth continued for $18 \mathrm{~h}$ (Fig. I). Glucose and ammonia were in excess, but the oxygen tension was not determined. Exopolysaccharide production continued maximally for another $20 \mathrm{~h}$ during the stationary phase before the rate of production eventually began to decrease, possibly because of low oxygen 


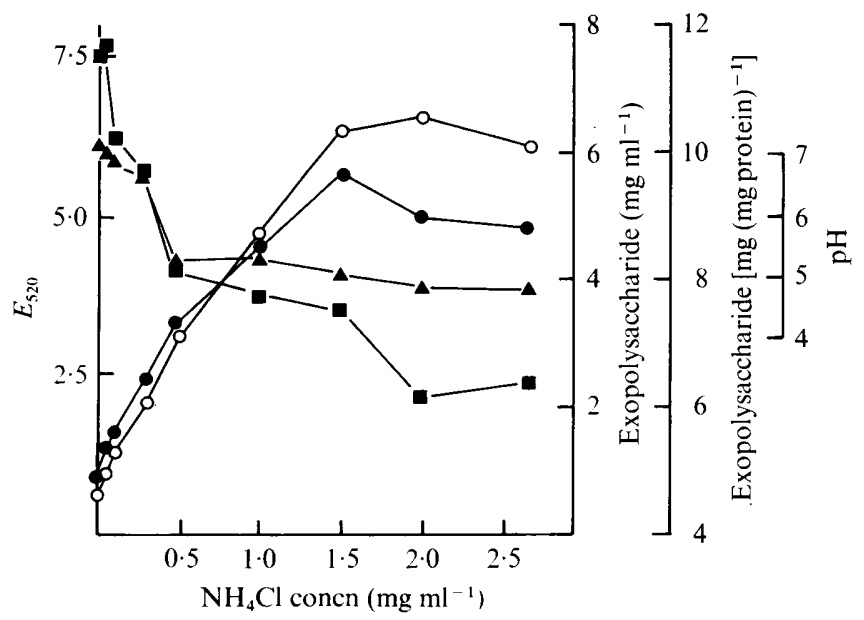

Fig. 2. The effect of the initial $\mathrm{NH}_{4} \mathrm{Cl}$ concentration on precipitable exopolysaccharide $\left(\mathrm{mg} \mathrm{ml}^{-1}\right)$ $(\bullet), \mathrm{E}_{520}(\bigcirc)$, and exopolysaccharide yield $\left[\mathrm{mg}(\mathrm{mg} \text { protein })^{-1}\right](\mathbf{a})$ after $48 \mathrm{~h}$ gyratory incubation (I20 rev. $\mathrm{min}^{-1}$ ) at $30 \pm \mathrm{I}^{\circ} \mathrm{C}$. The final culture $\mathrm{pH}$ is shown $(\Delta)$.

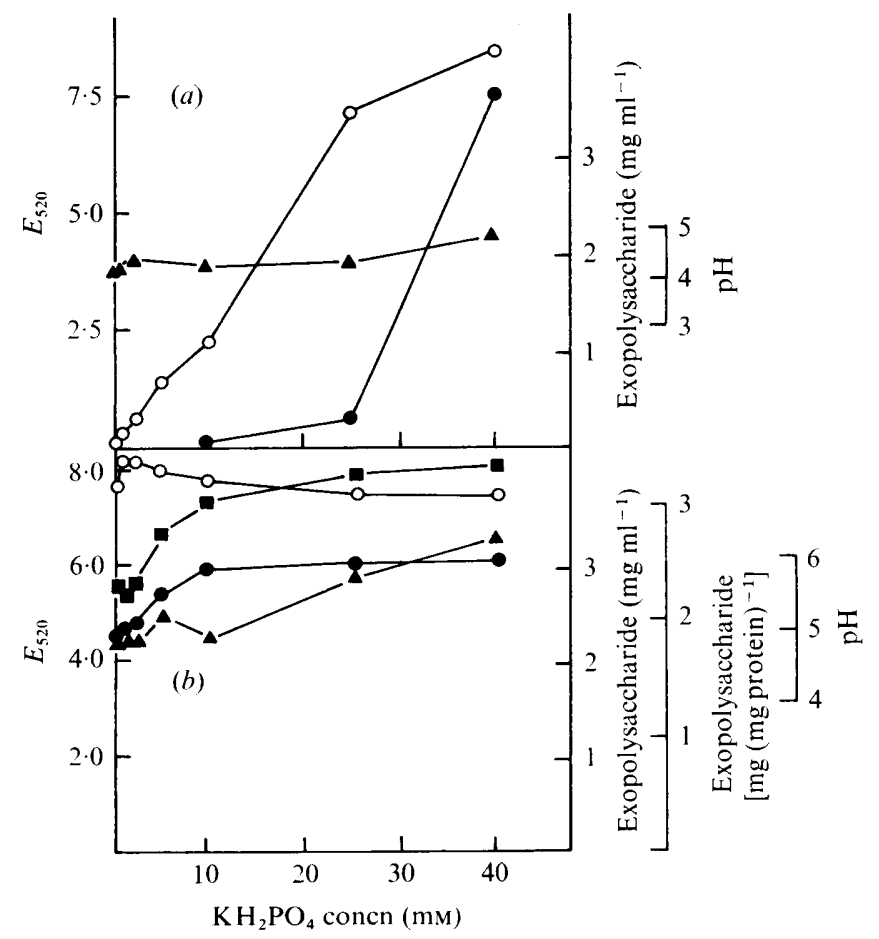

Fig. 3. (a) The effect of the initial phosphate content of the defined medium on precipitable exopolysaccharide (๑), $E_{520}(\bigcirc)$, and final culture $\mathrm{pH}(\bullet)$. (b) As $(a)$, but with $0.05 \mathrm{M}-\mathrm{Tris} / \mathrm{HCl}(\mathrm{pH} 8)$ in the defined medium. In addition the exopolysaccharide yield [mg (mg protein) $\left.{ }^{-1}\right]$ is shown ( $(\mathbf{m})$. 


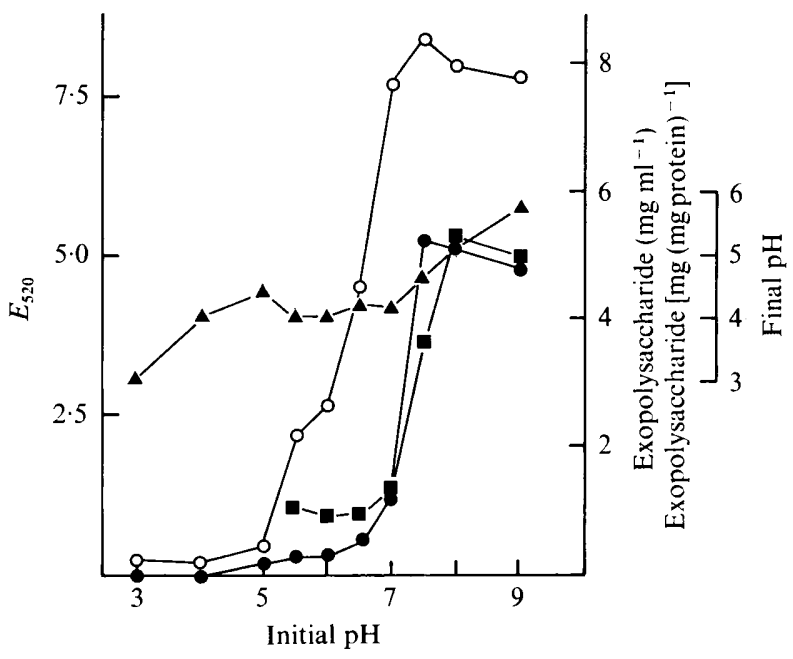

Fig. 4. The effect of the initial $\mathrm{pH}$ of the defined medium on precipitable exopolysaccharide $(\odot)$, exopolysaccharide yield $\left[\mathrm{mg}(\mathrm{mg} \text { protein })^{-1}\right](\square), E_{520}(\bigcirc)$, and final pH $(\Delta)$ after $48 \mathrm{~h}$ incubation.

tension due to the high viscosity of the culture and the decreasing $\mathrm{pH}$. This fermentation pattern is typical of secondary metabolite formation. Only $30 \%$ of the glucose utilized was converted into exopolysaccharide; the other $70 \%$ was presumably metabolized to establish and maintain the culture.

\section{Polysaccharide formation and medium composition}

The effects of nutrient concentration on yields of bacteria and polysaccharide were examined in a series of shaken flask experiments. Washed suspensions of polysaccharideproducing cells ( $15 \mathrm{~h}$ cultures) were used as inocula and polysaccharide was recovered from cell-free culture supernatants by propan-2-ol precipitation followed by drying and weighing.

Exopolysaccharide production was stimulated by a reduction of the nitrogen content of the medium in the presence of excess carbon substrate (Fig. 2). The lower polysaccharide levels at higher culture densities may be related to the final $\mathrm{pH}$ which decreased as the ammonium chloride, and hence final cell density, increased. Lowering the amount of phosphate in the medium did not enhance exopolysaccharide production because it reduced the buffering capacity and the $\mathrm{pH}$ soon fell (Fig. $3 a$ ). However, when the buffering capacity of the medium was increased with $0.05 \mathrm{M}-\mathrm{Tris} / \mathrm{HCl}(\mathrm{pH} 8)$, phosphate concentration had little effect on the final polysaccharide yield (Fig. $3 b$ ). At a phosphate concentration of I $\mathrm{mm}$ the final polysaccharide yield was reduced by 25 to $30 \%$. Maximum polysaccharide production ( 5 to $6 \mathrm{mg} \mathrm{ml}^{-1}$ ) could thus be obtained by reducing the ammonium chloride content of the medium provided that the mineral salt concentration was in excess of $4 \mathrm{ml}^{-1}$.

Increasing the initial $\mathrm{pH}$ of the medium favoured cell growth and polysaccharide production in that the final $\mathrm{pH}$ remained higher (Fig. 4). The $\mathrm{pH}$ of the fermentation was not controlled, either by the inclusion of specific buffers or through the metered addition of acid or alkali as necessary. The environmental $\mathrm{pH}$ appears to be a critical factor influencing polysaccharide production which should be controlled throughout the fermentation.

Yields of bacteria and polysaccharide rose with increasing initial glucose concentrations up to $2 \%(w / v)$ glucose (Fig. $5 a$ ) but did not increase above this concentration. Similarly, with sucrose as carbon substrate neither bacterial nor exopolysaccharide yields could be enhanced by increasing the initial concentration of carbohydrate to levels above $2 \%(w / v)$ (Fig. $5 b$ ). 




Fig. 5. The effect of the initial concentrations of glucose $(a)$ and sucrose $(b)$ on the $48 \mathrm{~h}$ batch incubation: precipitable exopolysaccharide in the fermentation liquor (O), exopolysaccharide yield $\left[\mathrm{mg}(\mathrm{mg} \text { protein })^{-1}\right](\mathbf{\square}), E_{520}(\bigcirc)$, and culture pH $(\Delta)$.

Water-soluble extracellular pigments were also secreted into the medium, the colour of which was apparently influenced by the ratio of carbon to nitrogen in the medium and ranged from red-purple at the lowest $\mathrm{C}: \mathrm{N}$ ratios examined to yellow-green at the higher $\mathrm{C}: \mathrm{N}$ ratios. These pigments, however, did not discolour the exopolysaccharide material recovered by propan-2-ol precipitation.

Polysaccharide production from a variety of carbon substrates $(\mathrm{I} \%, \mathrm{w} / \mathrm{v})$ in defined media was also examined in a series of shaken flask experiments. The $\mathrm{NH}_{4} \mathrm{Cl}$ content of the medium was reduced to $\mathrm{I} \mathrm{mg} \mathrm{ml}^{-1}$ to favour exopolymer production. The medium was inoculated with a standard inoculum of an overnight carbon-limited culture, and exopolysaccharide production was estimated after $48 \mathrm{~h}$ incubation following propan-2-ol precipitation (Table I). Samples of the cell-free dialysed material were hydrolysed $\left(0.5 \mathrm{M}-\mathrm{H}_{2} \mathrm{SO}_{4}\right.$, I00 ${ }^{\circ} \mathrm{C}$, I $6 \mathrm{~h}$ ) and the component monosaccharides were identified by descending paper chromatography. Analyses for total hexose, deoxyhexose and acetate were also performed on the undegraded polymeric material. Pyruvate was estimated after partial acid hydrolysis (Table I).

The organism was able to synthesize exopolysaccharide from a variety of mono-, di- and trisaccharide carbon substrates. The polysaccharide yields were generally higher for hexose than pentose utilization, except that growth on xylose led to greater polysaccharide production than the corresponding fermentation of galactose or mannose. Of the hexoses, glucose and fructose gave the highest polysaccharide yields, whilst the disaccharides sucrose, maltose and lactose were also good growth substrates and led to high polysaccharide yields. The trisaccharide raffinose was less satisfactory as a substrate both for growth and polysaccharide production. Of the non-sugar carbon substrates, sodium pyruvate and sodium succinate supported growth and polysaccharide synthesis. 


\section{Table I. Extracellular polysaccharide production by Pseudomonas NCIBI I 264 grown on various carbon substrates}

\begin{tabular}{|c|c|c|c|c|c|c|}
\hline \multirow[b]{2}{*}{$\begin{array}{l}\text { Carbon source } \\
(\mathrm{I} \%, \mathrm{w} / \mathrm{v})\end{array}$} & \multirow[b]{2}{*}{$E_{520}$} & \multirow[b]{2}{*}{ Final $\mathrm{pH}$} & \multirow[b]{2}{*}{$\begin{array}{l}\text { Exopoly- } \\
\text { saccharide } \\
\left(\mathrm{mg} \mathrm{ml}^{-1}\right)\end{array}$} & \multicolumn{3}{|c|}{ Composition of polysaccharide $(\%)$} \\
\hline & & & & Hexose & Acetate & $\begin{array}{l}\text { Pyruvic } \\
\text { acid }\end{array}$ \\
\hline Glucose & 4.9 & $6 \cdot I$ & $3 \cdot 23$ & $75^{\circ} \circ$ & 3.5 & $5 \cdot 6$ \\
\hline Galactose & $4 \cdot 7$ & $6 \cdot 4$ & $1 \cdot 92$ & $72 \cdot 8$ & $3 \cdot 6$ & $6 \cdot 3$ \\
\hline Mannose & $5 \cdot I$ & $6 \cdot 4$ & $I \cdot 74$ & $76 \cdot 0$ & $3 \cdot 7$ & $5 \cdot 5$ \\
\hline Fructose & $4 \cdot 9$ & $6 \cdot 4$ & $3 \cdot 39$ & $69 \cdot 4$ & $3 \cdot 4$ & $6 \cdot 6$ \\
\hline Xylose & $5 \cdot 3$ & $6 \cdot 3$ & $2 \cdot 20$ & $67 \cdot 3$ & $3 \cdot 8$ & $6 \cdot 5$ \\
\hline Rhamnose & $3 \cdot 3$ & $4 \cdot 8$ & 0.43 & $74 \cdot 4$ & $3 \cdot 4$ & $8 \cdot 8$ \\
\hline Arabinose & $3 \cdot I$ & $6 \cdot 5$ & $I \cdot 14$ & $70 \cdot 0$ & $3 \cdot 5$ & $5 \cdot 7$ \\
\hline Ribose & 49 & $6 \cdot 6$ & $I \cdot 89$ & $72 \cdot 1$ & $3 \cdot 2$ & $5 \cdot 4$ \\
\hline Lactose & $5 \cdot 3$ & $6 \cdot 5$ & 3.40 & $79 \cdot 7$ & $3 \cdot 8$ & $5 \cdot 2$ \\
\hline Maltose & $5 \cdot I$ & $6 \cdot 5$ & $2 \cdot 65$ & $79 \cdot 7$ & 4.0 & $6 \cdot 3$ \\
\hline Sucrose & 4.9 & $6 \cdot 2$ & $2 \cdot 87$ & $73 \cdot 6$ & $3 \cdot 8$ & $5 \cdot 8$ \\
\hline Raffinose & $3 \cdot 9$ & $6 \cdot 5$ & 0.60 & $74 \cdot 0$ & 3.9 & $7 \cdot 0$ \\
\hline Sodium pyruvate & $4 \cdot 3$ & $8 \cdot 9$ & $x \cdot 55$ & $79 \cdot 4$ & $3 \cdot 5$ & $6 \cdot x$ \\
\hline Sodium succinate & 3.0 & $7 \cdot 8$ & $\mathrm{I} \cdot 30$ & $78 \cdot 8$ & $3 \cdot 5$ & $6 \cdot 2$ \\
\hline Sodium acetate & $2 \cdot 2$ & $7 \cdot 7$ & 0 & - & - & - \\
\hline
\end{tabular}

The composition of the extracellular polysaccharide formed was independent of the initial carbon substrate (Table I). Although rhamnose could be detected chromatographically in all hydrolysates the small amount present could not be accurately measured using the cysteine-sulphuric acid colorimetric assay due to interference by the large amount of hexose in the polysaccharide. After correction for the hexose component, the deoxyhexose in all the samples analysed was estimated to be less than $10 \%$ of the total sugar.

The micro-organism could not use its own exopolysaccharide as a carbon substrate. Washed carbon-limited bacteria were resuspended in $0.01 \mathrm{M}-\mathrm{KH}_{2} \mathrm{PO}_{4}(\mathrm{pH} 7 \cdot 4)$ and inoculated into the defined medium containing the exopolymer $\left(5 \mathrm{mg} \mathrm{ml}^{-1}\right)$ as the sole carbon source. The polysaccharide did not support further growth of the organism and remained undegraded after Io days incubation.

\section{DISCUSSION}

The amount of extracellular polysaccharide formed by Pseudomonas NCIBII 264 was influenced by the cultural conditions. The organism was nutritionally non-demanding and the exopolysaccharide was formed in a chemically defined medium from a wide range of carbon substrates. Polysaccharide production was favoured by a high carbon: nitrogen ratio in the growth medium and, as with Z. ramigera (Parsons \& Dugan, I97I), the composition of the exopolymer synthesized was independent of the carbon and energy source. This independence is typical of microbial exopolysaccharide formation, although exceptional species require a specific carbon substrate for polysaccharide synthesis. For example, starch and dextrins are essential carbon substrates for the production of polysaccharide by Achromobacter mucosum (Ozawa et al., I972).

Exopolysaccharide production by Pseudomonas NCIBII264 in defined medium was, in common with synthesis in many other bacteria (Duguid \& Wilkinson, I953; Corpe, 1964), enhanced by nitrogen limitation in the presence of excess carbohydrate. Nitrogen limitation also favoured polysaccharide formation by the yeasts Pullularia pullulans (Catley, 1971) and Coccidioides immitis (Pappagianis \& Kobayashi, 1958) although cellulose formation by Acetobacter acetigenum was not similarly enhanced (Dudman, 1959). Increased exopoly- 
saccharide, as reported for strains of Aerobacter, Escherichia (Duguid \& Wilkinson, 1953) and Mycobacterium lacticolum (Gogoleva et al., 1976), was not observed under conditions of phosphate limitation. At low phosphate concentrations the buffering capacity of the medium was decreased so that during the course of the fermentation the $\mathrm{pH}$ fell to a point at which polysaccharide formation was suppressed. The response of Pseudomonas aeruginosa to an acidic $\mathrm{pH}$ was similar to that of Pseudomonas NCIBI 264 (Goto et al., 1973). The $\mathrm{pH}$ optimum for exopolysaccharide production depends on the individual species, but is near neutrality for most bacteria (Wilkinson, 1958). Moraine \& Rogovin (I97I) demonstrated that xanthan gum could be more efficiently produced in higher yields by continuously controlling the $\mathrm{pH}$ of the fermentation liquor.

Polysaccharide production by non-proliferating washed cell suspensions of Pseudomonas NCIBI I 264 was enhanced by the inclusion of the salts solution in the incubation (Williams, 1974), whilst both growth and polymer synthesis were reduced in shaken flask cultures containing less than $4 \mathrm{ml}^{-1}$ of this solution. Differences in the mineral requirements of polysaccharide-forming bacteria have been reported and whereas the inclusion of $\mathrm{K}^{+}, \mathrm{Mg}^{2+}$ or $\mathrm{Ca}^{2+}$ is known to be essential for the maximum synthesis of polysaccharide, sulphate limitation can either stimulate or inhibit, depending on the strain and the polymer formed (Duguid \& Wilkinson, I954; Markovitz \& Sylvan, 1962). The omission of $\mathrm{Fe}^{2+}$ ions from the growth medium of Chromobacterium violaceum led to increased polysaccharide synthesis (Corpe, 1964), although $\mathrm{Fe}^{2+}$ ions and sulphite were shown to stimulate the production of a proteinaceous slime by $P$. aeruginosa (Palumbo, 1972, 1973). The inclusion of phosphate and trace elements, in particular $\mathrm{FeSO}_{4}$, in a defined medium was essential for slime formation by strains of $P$. aeruginosa (Goto et al., I97I, 1973). Thus, whereas the salts solution used was sufficient to allow expolysaccharide synthesis by Pseudomonas NCIBII264, increased production might be obtained through a detailed investigation of the mineral and trace element requirements.

The time-course of exopolysaccharide production by Pseudomonas NCIBII 264 differed from that of many species in that polymer formation was not concomitant with growth. Unlike Xanthomonas campestris which formed xanthan gum throughout the fermentation (Moraine \& Rogovin, 1973), in our bacterium exopolysaccharide production did not commence until late in the exponential phase of growth although production continued maximally during the stationary phase. As with the xanthan fermentation, the rate of formation declined as the viscosity increased. However, whereas $75 \%$ of the glucose consumed by $X$. campestris was converted into xanthan gum, only $30 \%$ was transformed into exopolysaccharide by Pseudomonas NCIBI I 264, although pH control with a reduced nitrogen content should lead to increased fermentation efficiency. Parsons \& Dugan (197I) estimated that Z. ramigera converted approximately $34 \%$ of the glucose substrate into an exopolysaccharide matrix which was also formed when cell multiplication had ceased. Similarly polysaccharide production by $P$. fluorescens (Eagon, 1956) and Zoogloea MP6 (Unz \& Farrah, 1976) occurred in the late exponential and stationary phases of growth.

A.G.W. acknowledges the receipt of a C.A.P.S. studentship from the Science Research Council and Tate and Lyle Ltd.

\section{REFERENCES}

Brown, M. R. W., Scott-Foster, J. H. \& Clamp, J. R. ( I969). Composition of Pseudomonas aeruginosa slime. Biochemical Journal 112, 52 I-525.

Catley, B. J. (I97I). Role of $\mathrm{pH}$ and nitrogen limitation in the elaboration of the extracellular polysaccharide pullulan by Pullularia pullulans. Applied Microbiology 22, 650-654.

Corpe, W. A. (1964). Factors influencing growth and polysaccharide formation by strains of Chromobacterium violaceum. Journal of Bacterio$\log y 88,1433-1438$.

Dische, Z. (I962a). Colour reactions of hexoses. Methods in Carbohydrate Chemistry I, 488-494.

Dische, Z. (1962 b). Colour reactions of 6-deoxy-, 3-deoxy- and 3,6-dideoxyhexoses. Methods in Carbohydrate Chemistry 1, 501-503. 
Dubois, M., Gilles, K. A., Hamilton, J. K., Rebers, P. A. \& Smith, F. (1956). Colorimetric method for the determination of sugars and related substances. Analytical Chemistry 28, 350-356.

Dudman, W. F. (1959). Cellulose production by Acetobacter acetigenum in defined medium. Journal of General Microbiology 21, 327-337.

Duguid, J. P. \& Wilkinson, J. F. (I953). The influence of cultural conditions on polysaccharide production by Aerobacter aerogenes. Journal of General Microbiology 9, 1 74-189.

Duguid, J. P. \& Wilkinson, J. F. (I954). Note on the influence of potassium deficiency upon production of polysaccharide by Aerobacter aerogenes. Journal of General Microbiology 11, 71-73.

EAGON, R. G. (1956). Studies on polysaccharide formation by Pseudomonas fluorescens. Canadian Journal of Microbiology 2, 673-676.

Friedman, T. E. \& Haugen, G. E. (I943). Pyruvic acid. II. The determination of keto acids in blood and urine. Journal of Biological Chemistry 147, 4I5-442.

Gogoleva, E. V., Maksimov, V. N., GrechushKINA, N. N. \& Egorov, N.S. (1976). Optimisation of the medium and importance of some of its components for the biosynthesis of exopolysaccharide by Mycobacterium lacticolum. Mikrobiologiya 86, 800-805.

Goto, S., ENomoto, S., TAKahashi, Y. \& MotoMatsu, R. (I97I). Slime production by Pseudomonas aeruginosa. I. Conditions for slime production by the cellophane plate method. Japanese Journal of Microbiology 15, 317-324.

Goto, S., Murakawa, T. \& Kuwahara, S. (I973). Slime production by Pseudomonas aeruginosa. II. A new synthetic medium and conditions suitable for slime production by Pseudomonas aeruginosa. Japanese Journal of Microbiology 17, 45-5I.

Gray, C. T., WimpenNy, J. W. T., Hughes, D. E. \& Mossman, M. R. (1966). Regulation of metabolism in facultative bacteria. Structural and functional changes in Escherichia coli associated with shifts between the aerobic and anaerobic states. Biochimica et biophysica acta $117,22-32$.

Lowry, O. H., Rosebrough, N. J., FarR, A. L. \& RANDALl, R. J. (I95I). Protein measurement with the Folin phenol reagent. Journal of Biological Chemistry r93, 265-275.

MCComb, E. A. \& MCCready, R. M. (1957). Determination of acetyl in pectin and in acetylated carbohydrate polymers. Hydroxamic acid reaction. Analytical Chemistry 29, 819-82 I.

Markovitz, A. \& Sylvan, S. (1962). Effect of sodium sulphate and magnesium sulphate on heteropolysaccharide synthesis in Gram-negative soil bacteria. Journal of Bacteriology 83, 483-489.
Moraine, R. A. \& Rogovin, P. (I97I). Xanthan biopolymer production at increased concentration by $\mathrm{pH}$ control. Biotechnology and Bioengineering I3, 38I-39I.

Moraine, R. A. \& Rogovin, P. (1973). Kinetics of the xanthan fermentation. Biotechrology and Bioengineering $15,225-237$.

OzaWa, Y., Yamada, K., Kobayashi, H. \& SuzuKi, H. (1972). Production of polysaccharide from starch and identification of constituent sugars of the preparation. Agricultural and Biological Chemistry 36, $2117-2122$.

Palumbo, S. A. (1972). Role of iron and sulphur in pigment and slime formation by Pseudomonas aeruginosa. Journal of Bacteriology III, 430-436.

Palumbo, S. A. (1973). Influence of sulphite on growth, slime and fluorescent pigment production by Pseudomonas aeruginosa. Canadian Journal of Microbiology 19, 505-5II.

Pappagianis, D. \& Kobayashi, S. (1958). Production of extracellular polysaccharide in cultures of Coccidioides immitis. Mycologia 50, 229-238.

Parsons, A. B. \& Dugan, P. R. (I97I). Production of extracellular polysaccharide matrix by Zoogloea ramigera. Applied Microbiology 21, 657-661.

Skujins, J. J., Potgieter, H. J. \& Alexander, M. (1965). Dissolution of fungal cell walls by a streptomycete chitinase and $\beta-(I \rightarrow 3)$-glucanase. Archives of Biochemistry and Biophysics 111, 358364.

Solorzano, L. (1969). Determination of ammonia in natural waters by the phenol-hypochlorite method. Limnology and Oceanography $\mathbf{1 4}, 799-80 \mathrm{I}$.

Sutherland, I. W. (1972). Bacterial exopolysaccharides. Advances in Microbial Physiology 8, I43-2I3.

UNZ, R. F. \& FARRAH, S. R. (1976). Exopolymer production and flocculation by Zoogloea MP6. Applied and Environmental Microbiology 31, 623-626.

WILKINSON, J. F. (1958). Extracellular bacterial polysaccharides. Bacteriological Reviews 22, 46-69.

Williams, A. G. (1974). Extracellular polysaccharide production by a Gram-negative bacterial isolate. Ph.D. thesis, University of Wales.

Williams, A. G. \& Wimpenny, J. W. T. (I976). Exopolysaccharide production by Pseudomonas PBI grown in batch and continuous culture. Effect of growth conditions. Journal of Applied Chemistry and Biotechnology 26, 326-327.

Williams, A. G., WimpenNy, J. W. T. \& Lawson, C. J. (I973). The production of an extracellular polysaccharide by a Pseudomonas-type microorganism. Journal of General Microbiology 77, xiii. 